Portland State University

PDXScholar

6-16-2021

\title{
The Transition of American Theatre Due to the COVID-19 Pandemic from March 2020-May 2021
}

Taylor Fischer

Portland State University

Follow this and additional works at: https://pdxscholar.library.pdx.edu/honorstheses

Part of the Other Theatre and Performance Studies Commons, and the Performance Studies Commons

Let us know how access to this document benefits you.

\section{Recommended Citation}

Fischer, Taylor, "The Transition of American Theatre Due to the COVID-19 Pandemic from March 2020-May 2021" (2021). University Honors Theses. Paper 1073.

https://doi.org/10.15760/honors.1099

This Thesis is brought to you for free and open access. It has been accepted for inclusion in University Honors Theses by an authorized administrator of PDXScholar. Please contact us if we can make this document more accessible: pdxscholar@pdx.edu. 
The Transition of American Theatre due to the COVID-19 Pandemic from March 2020-May 2021

by

\section{Taylor Fischer}

An undergraduate honors thesis submitted in partial fulfillment of the requirements for the degree of

Bachelor of Arts

in

University Honors

and

Theatre

Thesis Adviser

Karin Magaldi

Portland State University 


\begin{abstract}
Due to the coronavirus pandemic, the theatre industry had to make massive shifts from March 2020 through May 2021. Many theatres went out of business because there was a lack of government funds available for the arts and entertainment industries.

However, some theatres turned to virtual productions or in-person shows that meet CDC guidelines while others shut down completely. This paper describes the transitions made in the American theatre industry due to the pandemic through my experience working on a virtual production and interviews conducted with other artists.

I assistant directed a virtual production of Top Girls at Portland State University during the pandemic. I will be utilizing my experience working on the show to describe some of the pros and cons of virtual theatre. I also conducted interviews with two theatre artists who worked on productions in the pandemic, Kay Cates and Olivia Henry. I will be using their experience as well as my own to highlight the shifts in theatre during the pandemic. Virtual theatre allows for a re-imagination in the form of productions. It makes people more creative and helps art become more accessible. However, virtual theatre lacks the chemistry and unique live quality of theatre, but in-person shows that meet CDC guidelines were still able to possess this.
\end{abstract}

\title{
Background
}

COVID-19 was first reported in the United States in January of 2020 and since then it has devastated many American businesses; the arts and entertainment industry has taken some of the biggest hits. As of May 15th, 2021 there are now over 32 million cases of COVID-19 in the United States alone and due to government shutdowns, there are also millions of people now unemployed (CDC COVID Tracker). COVID-19 has had some of 
the biggest impacts on the theatre industry. Broadway closed on March 12, 2020, and if it reopens when scheduled in May 2021, the closure will have lasted 444 days making it the longest shutdown in Broadway's history (Jones). Theaters did not receive the same amount of government aid as other industries which makes it incredibly challenging for theatre companies and artists to stay afloat. Many theaters and Broadway have shut their doors until the pandemic is under control and some theaters have unfortunately permanently shut down due to the lack of financial support during the pandemic.

The coronavirus pandemic is not the first time theaters have shut down, but it is the first major shut down of theatres all over the world while having widespread internet access. In New York City, for example, theaters closed for two days as a result of 9/11/2001. Previous to that, theatres shut down in 1918 when the Spanish Flu hit the United States. Elizabethan theatres in England also had to stop performances during the bubonic plague on and off for a total of 78 months ("From Pandemics to Puritans"). Unlike the Elizabethan theatre, we have advanced technology that allows for a transition to virtual shows during our time of crisis. Remote theatrical productions have gained widespread popularity due to our technology. Theatres are finding new ways to cope and the changing format of productions has opened up innovative creative opportunities despite these arduous conditions.

In response to the circumstances, numerous theaters have also been creating various forms of virtual productions and attempting to make in-person theatre follow CDC requirements. Theatre is a collaborative performing art that involves artists in front of a live audience. The definition of live means emitted at the time of occurrence and not from a recording. It is hard for artists to maintain the live aspects of theatre when moving 
productions to a virtual space because it takes away the elements of a live audience or performers. This can turn theatre productions into film performances which many theatre professionals want to avoid. Other theatre companies have moved to in-person productions that are outdoors, socially distanced audiences, and requiring masks to meet CDC guidelines.

I assistant directed and interviewed other artists working in the pandemic to compare the different ways theatres shifted from March 2020 through May 2021. I assistant directed a virtual production of Top Girls in the Spring term of 2021 at Portland State University. I am using my experience working as an assistant director for a virtual production to illustrate how theatre is transforming due to the pandemic from March 2020-June 2021. Since COVID-19 is a current event, there is not a lot of research about how it is impacting theatre. I interviewed other theatre artists who have also worked on productions during the pandemic and I am using all of our different encounters to compare the various ways theatre is modifying.

\section{Process of Assistant Directing a Virtual Production}

My process of assistant directing began with reading two different plays and discussing which play would be better suited for the virtual landscape. The two scripts I read were Top Girls by Caryl Churchill and Ludlow Fair by Lanford Wilson. There were different pros and cons to each show. Top Girls is great because it has a larger cast which allows for more actors while Ludlow Fair takes place in a bedroom making it suitable for an online format. The con of Top Girls is the show is complex which makes it quite challenging to do virtually. Ludlow Fair is less difficult to do virtually because of the setting, but the director was concerned the show was not as intriguing. We decided to do 
Act I of Top Girls for the Spring 2021 production because we thought the actors would be more excited to work on it which is vital in the time of the coronavirus. It is crucial artists find ways to keep their creativity active and still get to make art during the pandemic.

The next part of preparing for the show was casting. I created a list of the characters who speak from most to least in the play in order to aid in casting. Then we had actors submit audition tapes of them performing a 1-2 minute contemporary monologue and from those videos, we selected actors for callbacks. The callbacks were held virtually on Zoom using breakout rooms to call actors into the room to read sides whilst other actors waited in the main room. One of the biggest differences with casting online is that the chemistry between the actors is less apparent. The chemistry of actors being in the same room is distinct and this is missing in virtual productions. Instead, the casting process was more focused on how actors' voices sounded together for the online format. Based on the callbacks, we selected the cast for Top Girls which consists of six women characters.

Before the rehearsals began with the actors for Top Girls, I had a few discussions with the director where we talked about how we would handle certain elements of the script virtually. The first act of Top Girls is a dinner party at a restaurant where characters are ordering food, eating, and talking. One of the challenges with doing this production virtually is how to handle the food because it is difficult to make it look like all the actors are sharing bread at a restaurant when they are all in individual rooms in virtual boxes. I created a list of all the food in the production and when it is on and off stage, so we could keep track of the food in the show. Additionally, I gathered images of all the food in the 
production for the design team to look at to see how to recreate the characters' meals in a way that looks similar even if it is not exact.

In the first week of rehearsals, we decided that there will be a pre-show speech by one of the actors establishing the background for the show. The director decided that the show should take place in the Fall of 2020 during the pandemic and the actors are at a dinner with socially distanced tables, so the setup for the production makes more sense to audiences. This will be theatrically explained to audiences in the pre-show speech. We also discussed some of the virtual elements of the show in a production meeting establishing that the actors will use green screens and eat real food since they are at a dinner party. During the first week of rehearsals, we also did a read-through of the script, assigned the actors an off-book date, and the actors were given questions to help them connect with the script and characters more. In the first week, the biggest difference with a virtual production I noticed is that it is difficult to get a uniform setup for all actors because it is mostly centered around camera angle which is something that does not happen during in-person productions.

During the next week of rehearsals, we started staging the production and had the actors' present character work. Staging the production was challenging to do through a virtual platform. We had a lot of discussion about how to make the actors look uniform in their chairs since they are all supposed to be in the same restaurant. We talked about how to frame the actors in the camera, so they are all viewed at a similar angle. This was very interesting to think about especially since I am also studying film and this combines the world of theatre and film. In order to avoid making the theatrical production from becoming too much like a film, it is important to keep the elements of a live audience and 
have multiple different recordings of the virtual performances, so the shows vary slightly which are unique qualities to the theatre. One of the most exciting parts of doing a virtual production is learning how to adapt traditional theatre into this unique format.

In the third week of rehearsal, we finished roughly blocking the production. One of the biggest challenges of doing a virtual production is that the show can start to lack physical life. I thought a lot about an idea brought up by Peter Brook in The Empty Space that it is impossible to understand a dramatic situation without physical movement (Brook 49). It is important to think about how to incorporate physicality into a virtual production and the food in this show helps to do that. The act of eating during this play gives the actors something more physical to do. Gestures and finding at least one moment in the show where a character can stand up also helps bring physicality to virtual productions. In the production Top Girls, there are only two moments in the show where characters get up since it is challenging to do this with only one camera set up for each actor. Nonetheless, it made the times when characters do stand up feel even more important since they were rare whereas, during in-person shows, actors frequently stand and change their physicality. The first three weeks of rehearsal focused on orienting the play and laying out the framework for the staging of the production. One of the biggest challenges I have noticed with virtual productions is finding a way for the character to still have physicality since they cannot move much and still be in the frame of the camera on the virtual setup.

Throughout the next two weeks of rehearsal, we polished the blocking of the production and incorporated more of the eating physicality into the show. We have the actors react to each other by either leaning forward or leaning back in the camera when 
the other character speaks. During these rehearsals, it became clear to me how much more difficult it is to capture the chemistry between the actors in the virtual format versus in-person. The actors cannot react to one another in person and there is no live audience. There is a certain chemistry that comes with audience members and actors being live together in the same room that is impossible to get in the virtual format. The absence of live chemistry can make virtual theatre feel like watching a film. This is one of the biggest cons of producing virtual theatre during the pandemic.

In the sixth week of rehearsal, we rehearsed more and came across a large issue with a virtual theatre. We learned that we could not secure rights to the Top Girls script in time, so we could longer perform the production in May as intended. Instead, we will now record the production in May, but audiences will not see it until September, so we have more time to obtain rights. This happened because the staff who provide rights to Top Girls are understaffed due to fewer people working in theatre during the pandemic. Because of this, the process was very delayed and they could not grant Portland State University the rights by May of 2021. This is very unfortunate as audiences will not get to see the work until months later and it is especially frustrating for students who are graduating and wanted their last production of college to be seen around the time they graduate. The issue we encountered securing rights is another example of one of the cons of making virtual theatre during the pandemic.

The next stage of working on Top Girls consisted of tech and the recording of the shows that audiences will see in September 2021. One of the biggest difficulties that came up in tech was learning that the show being recorded through a program called OBS reversed the actor's videos. This made it look like the actors were looking in the mirror 
and the images that the actors saw in their camera were different from how the audience view of it was. If an actor looked to their right, it would look like they were looking to their left to audiences. This caused a lot of issues, especially because the actors are supposed to look at other characters when they react to them. However, the actor would have to look in the opposite direction of where the character appears for them in order for it to read to the audience as if they were looking at that character. This resulted in all the blocking for the production looking reversed to audiences in tech. It would have been nice to learn about this issue prior to tech, so the show could have been blocked differently initially. Since we learned about this problem late in the rehearsal process, we ended up just leaving the blocking appearing reversed to audiences.

Overall, the process of assistant directing was very fulfilling. There are many unforeseen circumstances that appeared while working on a virtual production, but we were able to work through a lot of them effectively. Despite Top Girls being virtual, the actors and crew treated the show with just as much attention and integrity as an in-person show, if not more. It was a great experience to collaboratively work on art with others during a time of extreme isolation and to make theatre that is so reflective of our times. Although not Churchill's intent, there is a distinct quality to Top Girls at Portland State University being set in the pandemic with socially distanced tables and the character video calling. It also makes this production of Top Girls uniquely reflective of the time period of the pandemic from March 2020 through May 2021 in a way that most adaptations of this show are not.

\section{Other Artists Experiences with Theatre During the Pandemic}


Since theatre during the pandemic is a new topic there are not many research articles on it, I interviewed two people who have worked on different theatre productions in America since the beginning of the pandemic to demonstrate some of the ways that theaters are coping and creating art. The first interview I conducted was with Kay Cates who was the Properties Designer/Manager for several productions at Weathervane Theatre in New Hampshire during the pandemic. Cates has worked on in-person productions modified to meet CDC guidelines as well as some virtual productions. They helped me gain insight into the challenges of in-person theatre during the pandemic and some of the other ways different theaters approached virtual shows.

One of the most notable productions Cates worked on was Little Shop of Horrors at Weathervane Theatre because it was the first indoor show approved by Equity in America since theaters shut down in March 2020 due to the COVID-19 pandemic. Weathervane Theatre in Whitefield, New Hampshire, where Cates worked, was able to continue doing in-person theatre during the pandemic due to the unique situation of the theatre. Weathervane Theatre is a summer stock theatre where the production crew and cast live in a house together. This made it easier for the theatre to manage COVID-19 cases compared to most theatres. Due to the pandemic, everyone in the cast and crew quarantined before moving in and there were daily temperature checks. The theatre is also in a rural area in Coos County where there were less than 10 cases of COVID-19 in the entire county from January to the beginning of October 2020 (CDC COVID Tracker). The theatre only has a summer and fall season, meaning they were able to operate successfully due to the fact that there was no large outbreak in Coos Country. 
There were several modifications made to the production of Little Shop of Horrors, so it could be done during the pandemic. The actors and crew living in the house together had to quarantine before moving in and stay in the bubble for the time of the production. The rehearsals were socially distanced and outside for the first few weeks of the production for better airflow. Traditionally in Little Shop of Horrors, there is a person in an enclosed full-body plant costume, which restricts airflow. Due to COVID-19, they had a person in a bigger costume with more ventilation, so no one was in a tightly enclosed space. The audience was also reduced by a third of the normal capacity and had to get their temperature checked before entering. There was also a COVID-19 questionnaire and audiences had to wear masks for the whole show. The live production was very successful despite having to make changes due to the pandemic.

Additionally, Cates worked on virtual holiday productions at the Weathervane Theatre recorded in October 2020, edited, and released during December. Cates described how some of the holiday virtual shows were directed like filmed theatre on a stage from one angle. Whereas, other holiday productions were virtual shows that felt more like a film because they changed camera angles and edited it in post-production. Cates discussed one of the virtual holiday shows which involved magical elves on a subway. Due to the virtual nature of this production, the Weathervane Theatre was able to edit the show, so it looked like it was on a subway. This would not have been edited in this way if it were not a virtual production.

Cates was able to work on an in-person production that shifted to meet CDC guidelines with Little Shop of Horrors which is very different from my experience working on a virtual show. One of the main pros of in-person theatre is maintaining the 
chemistry between actors and the audience. There is also a stronger sense of community that I believe comes with doing in-person theatre due to the ability to connect with someone in real life. I do relate to Cates's accounts of working on a virtual production at the Weathervane. The transformation that editing had on the production was similar to my experience assistant directing Top Girls. The green screens in the virtual production of Top Girls allowed for it to look like all the actors were close up in a restaurant which could not have been done in the same way during an in-person show. One of the other special parts of doing a virtual production is that it allows for audiences to experience the show in a new way which is especially impactful for reimagining classic plays.

I also interviewed Olivia Henry about acting in a virtual theatre production of Anon(ymous) and Neighborhood 3: Requisition of Doom. The production of Anon(ymous) that Henry acted in was supposed to be a live-streamed show to a virtual audience where the actors were all live on stage socially distanced and wearing masks. This production, unfortunately, got canceled due to a crew member getting exposed to the virus during the run of the production. In spite of following strict protocols, the show was still canceled because the two-week quarantine period of the crew member was during the weeks when the performances of Anon(ymous) were supposed to take place. The other show Henry acted in, Neighborhood 3: Requisition of Doom, had actors record themselves, and then it was edited together for a live-streamed show. Henry stated that one of the main things required for virtual productions is patience and being adaptable. She also said that one of the hardest things about acting in a virtual theatre format was being able to see oneself in the camera and not being able to see an audience. She said "a lot of acting, in general, is feeding off of the nonverbal feedback that the audience gives you" and this is something 
that gets lost in doing virtual theatre (Henry). One of the pros of having a pre-recorded show is that it is less likely to be canceled and it allows for any technical glitches to get fixed. Pre-recording a show does make it less like theatre though and more similar to film productions. One thing that Henry emphasized is how wonderful it felt being in the theatre again and making art with others in a time of intense isolation.

One of the main positive results of virtual theatre is that it is more convenient for audiences since they do not have to leave their home. The ticket prices are typically lower for virtual shows, so more people who cannot usually afford to see live theatre are able to see it. Additionally, it is easier to self-produce virtual theatre since one does not have to rent a venue for rehearsals or performances. This could help diversify theatre-makers which is very good because the creators in this field are predominantly white men. Virtual shows could play a massive role in bringing more equality to theatre and productions such as the one Henry acted in Neighborhood 3: Requisition of Doom help expand the reach of theatre by making it accessible to everyone.

I resonated a lot with Henry's experience and there are many similarities to how I felt working on Top Girls. Some of the most challenging aspects of working on virtual productions are trying to have the same chemistry as in-person art and always being adaptable due to the constant changes due to COVID-19. While working on Top Girls, we had to adapt to several challenges including having issues securing rights due to fewer theatres being staffed during the pandemic. However, the constant need to adapt has made many artists more patient and resilient. Unfortunately, the entire performing arts industry had to change due to the virus, but there are many tremendous art pieces and lessons in the craft that are learned from it. 


\section{Conclusion}

One of the greatest ways that theatre was impacted by the pandemic is that it is far more accessible. Audiences are now able to access theatre online without even leaving their home. This makes it easier for disabled people to watch theatre and it allows for subtitles to be available in the virtual format for those who have impaired hearing. Many virtual theatre productions are free or significantly less expensive than in-person theatre, so it makes theatre more accessible to people of various socioeconomic statuses. In an industry that has traditionally had a wealthier older white audience, it is incredible to see how COVID-19 can play a role in diversifying audiences. Hopefully, this is something that continues after the pandemic. All theatre productions and professionals should work to make the greater accessibility of theatre that came with the pandemic a permanent change.

The most substantial drawback of virtual theatre is that it is less live. Even in productions where actors are performing live to a live-streamed audience, there is not the same chemistry as an in-person production. It is impossible to capture the actor's ability to feed off the audience members' laughter and reactions in a virtual format. Many virtual productions like the one Olivia Henry worked on titled Neighborhood 3: Requisition of Doom and Top Girls are pre-recorded, so it is missing the component of live actors completely. A lot of theatre productions have had to become more like films during the pandemic which is especially challenging for artists who do not have experience with film. This also takes away from the unique qualities of live theatrical productions.

All of this research contributes to the field of theatre by providing insight into remote productions that are not often talked about. There is very little research on virtual 
theatre and it may become increasingly popular in the future. Another event in the future may cause people to conduct art virtually again and it is important to discuss different ways that theaters have adapted, so there is more information on creating art remotely. It is uncertain when theaters will be able to function normally again. There could be a shift to the in-person theatre in the future when it returns as a result of the pandemic. There could be more pandemic-related theatre pieces that involve screens or more theatre productions could be recorded to increase accessibility. It is also possible in-person theatre will return with higher attendance due to people missing live shows. Until live theatre returns, virtual performances are extremely vital to keep people engaged in art and inspired in the challenging times of COVID-19.

Despite all the struggles with making art during the pandemic, both Cates and Henry made it clear to me they cherished their experiences and were happy they created theatre during the pandemic. I completely agree with them and I think the challenges of virtual theatre are absolutely worth it. More people are isolated than ever before and art is used to bring people together providing the masses with a sense of hope. Often, the best art gets constructed during periods of catastrophe, and it is rare for the entire world to experience an event together as we did with COVID-19. In the next few years, it will be compelling to see all of the theatre created around the world regarding the pandemic and how virtual theatre will shift the artistic landscape even when theatre returns in person. There are many modifications to theatre that were made from March 2020- June 2021 to cope with the pandemic, but it is unclear what the future will hold and if more changes will become necessary as the virus evolves. 


\section{Works Cited}

Brook, Peter. The Empty Space. Touchstone, 1996.

Cates, Kay. Personal interview. 21 January 2021.

"From Pandemics to Puritans: When Theatre Shut Down through History and How It Recovered." The Stage, The Stage Media Company, 1 Apr. 2020, www.thestage.co.uk/long-reads/from-pandemics-to-puritans-when-theatre-shut-do wn-through-history-and-how-it-recovered.

Henry, Olivia. Personal interview. 19 January 2021.

U.S. Department of Health \& Human Services. "CDC COVID Data Tracker." Centers for Disease Control and Prevention, Centers for Disease Control and Prevention, 21 Jan. 2020, covid.cdc.gov/covid-data-tracker/. 